\title{
Educational Transformation in Post-Independence Africa: A Historical Assessment of the Africanization Project
}

\author{
Roland N. Ndille, D.Litt. et Phil \\ Centre for Education Rights and Transformation, CERT \\ University of Johannesburg, SA \\ PO Box 524, Auckland Park 2006 \\ Johannesburg, SA \\ rndille@uj.ac.za \\ Teaching and Research Service, Faculty of Arts \\ University of Buea \\ PO Box 63, SWR, \\ Republic of Cameroon \\ roland.ndille@ubuea.cm
}

\begin{abstract}
Africanization of education was a major policy option in most countries in Africa upon the attainment of independence. This is because of the perceived negative effects of colonial education. The paper is an empirical sources study which discusses Africanization as an epistemicide and analyses efforts by some African states to Africanize their educational systems. It concludes that while some countries embraced the idea and actually initiated policies to Africanize their educational systems, the general picture indicates that Africanization has not succeeded in most countries due to various challenges. Such challenges are identified and recommendations made which could be significant for the revamping of the policy.
\end{abstract}

Key Words: Africanization, Transformation, Education, Reform, Challenges, Prospects

\section{Introduction}

More than fifty years ago, most African nations fought and acquired independence from their various colonial masters. Contrary to what Kwame Nkrumah implied by his seek ye first the political kingdom and all else shall be added, the forefathers of African nationalism on whose shoulders the establishment of African independent states rested came to the stark reality that independence went beyond seeking the political kingdom to establishing socio-economic and cultural institutions which were to represent the African states as unique entities with equal value to those that held them under the bondage of colonialism. Calls were made for reform within which a return to the African indigenous identity as a right in itself was highlighted. These reforms were to restore the past mutilated and abused African cultural base and were to serve as tools and values for the education of the future African generations. Using available 
empirical literature, this paper brings to limelight what the founders of African nations meant by africanization; discusses why it was necessary; assesses the terrain in different sectors of education and examines the challenges and prospects of Africanization of education. It concludes by proposing a future line of action for the sustenance of the project.

\section{The Colonial Education Experience}

Research and recounted experiences have ubiquitously revealed that colonialism brought about a rupture in every aspect of life in Africa from the traditional political institutions and indigenous economic developments to socio-cultural norms and values for its own sake [1] [2] [3]. In education, while colonial school authorities sponsored the assimilation of European contents, they carefully concealed issues which valorised local realities [4]. Wherever it was implemented, the colonial education project was to ensure that African natives should be as much as possible unaware of the developments within their own environment [5]. In primary, secondary as well as teacher training colleges and university centres, the use of European contents and language of instruction was ubiquitous. As late as 1952, the Advisory Committee on Education in British Tropical Africa confessed that 'there can be no doubt that education in British Tropical Africa has paid far too much regard to the content traditionally associated with the English elementary school and far too little to the African environment and the material which has reality and meaning for the African children as part of their experience' [6].

It is for such reasons that Walter Rodney, a pioneer in this line of research terms colonialism a one-armed-bandit [7]. Said, on his part has qualified colonial education as an organized form of imperialism that allowed colonial authorities to continue to indoctrinate new subjects [8] and in the process, succeeded in doing away with all outward signs of native life that children brought with them to the campus [9]. In fact many of the Africans we have read about, and those we had the luck to hear them recount their experiences with schooling in the colonial days have attested to 'the interpretive ideological valorisation of Euro-American society as superior, progressive and universal' [10] and the successful eradication of the vestiges of local African cultures.

It is important to mention however that within the north-south divide, research is not unanimous regarding the nature, implementation and outcome of colonial education as there exists a 
modernist revisionist historiography of education which claims [and particularly for Britain] that there was no central policy emanating from Europe which was particularly directed to the objectives we have mentioned above. They hold that "nowhere in the evidence is there an overt suggestion that the Europeans had any predetermined wish to dominate, subvert, or control the minds of Africans since (they argue) educational outcomes are often determined less by the initiators of policy than by those to whom the policy applies [11]. Whitehead claims, amidst serious objections[12] that British models of education were certainly followed not because they were deliberately imposed on colonial schools but rather because Africans and other colonial subjects insisted on them [13].

However, contemporary developments in British highest political circles have since discarded such thinking. During a visit to Pakistan in 2011, British Prime Minister David Cameron acknowledged that many of the modern world's problems were the product of Imperial Britain's legacy. In addition to other negative impacts, Cameroon pointed directly to the nature of colonial education as the root cause of contemporary former colonial people's miseries of civil strife, destitution, poverty, illiteracy, corruption, and the deep-rooted public sector inefficiencies, nepotism and underdevelopment [14]. Mr Cameron's remarks about the painful legacy of colonial education, for which Theresa May (the current Prime Minister) is being called by the Labour opposition party to tender an apology to colonial people [15] could not be further from the truth and reveals a disappointing lack of historical judgment on the part of those who attempt to shield colonial perpetrators.

By citing the above studies, it is my purpose here to show that between precolonial and colonial educational praxes, there was what Ali Mazrui termed 'cultural discontinuity' [16], and that After 'independence' there was every need for what Samir Amin termed 'delinking' or what Mignolo has recently called 'dewesternization' [17] which the African statesmen appropriated in Africanization; a call for the reorientation of education in favour of a locally based/contextualized system.

\section{Africanization of education: An Epistemicide}

Africanization has been one of the most discussed ideologies in Africa since the wind of change of the late 1950s. In the field of education it emanates from the premise that education is man's acquired experiences as (s)he interacts primarily with his/her environment. This interaction is an eternal process of adjustment, refinement, and improvement of that society. It is therefore a process of transmission of what is worthwhile to those who become committed to it [18]. 
Education is expected to initiate each individual into the general culture of his/her community and ensure that the transmission of the culture is sustained [19]. This understanding presupposes that there is a definite connection between culture, the aims of education and the content. The content of education is the school curriculum and its choice is primarily determined by the aims of education set by the society concerned which in turn determines the structure of the educational system and its sustainability. These are expected to be unique as societies are unique in their composition, past experiences, daily challenges, world view and future plans.

In fact, Confucius, the famous Chinese philosopher was very uncompromising to the study of other societies, at least not without a firm mastery of one's own knowledge base. He explains that the 'study of strange doctrines is injurious indeed' and that 'earning in every society requires that the people should be 'true to the principles of their society and the benevolent exercise of these principles to others- this and nothing more' [20]. This is what is meant by education being 'crucial for the preservation of the lives of its members, maintaining the social structure and promoting social change [21]. Mwinzi has talked of an African epistemology being deeply ingrained in the metaphysical and spiritual traditions of Africa ${ }^{22}$ while Aquinas had long time intimated that cognition is brought about by the presence of the known object in the knower(s) mind(s) and that the object can only be in the knower(s) after the fashion of their own nature. [23]

What is generally deciphered from the conceptualizations of education is that, worthwhile education should grow out of the environment and the learning process should be directly related to the pattern of life in the society concerned. It should be that which generally constitutes the totality of the human faculty of that society resulting from a combination of commonly held societal data, experiences, needs and projections [24]. These are embedded not only in documents or repositories but also in societal routines, processes, practices, and norms [25].These issues were not new in Africa. They were simply displaced, distorted and made to appear irrelevant by those who held the power of agency during colonialism [26]. This compounded the task of the school which emerged out of colonialism as relevance became the most crucial ontological condition for educational policy. There was therefore a need for restitution of relevant contents and structure when the power of agency was handed back to the Africans. This restitution is what has taken the ideological direction of Africanization [27]. 
As an epistemicide therefore, Africanization is generally seen as a renewed focus on Africa, to reclaim what has been taken from Africa [28]. It includes all the calls for African consciousness about 'ourselves; to liberate ourselves; to decolonise our minds; and to emancipate ourselves from mental slavery implanted in us by European colonisation and to develop ourselves with our own uniquely thought-out frameworks, strategies and resources of implementation [29].' This is done with the fundamental conviction that such a project will lead to the total liberation of the continent from coloniality and a re-centring of Africa on an egalitarian basis with the rest of the world. The Africanization project encompasses all efforts embedded in Afrocentricity, localization and indigenisation of knowledge [30].

Within education, Africanization is a restorative justice project which sees justice in the perspective that each person must have an equal right to the most extensive liberty compatible to a similar liberty with others. It consists of setting up local contents curricula, and proliferating the use of African mother tongues in the development and dissemination of knowledge in African institutions of learning and in the establishment of unique structures of education based on African indigenously established purposes; making African institutions, and not merely institutions in Africa [31].According to Nkoane an Africanized educational system is one which

Maintains African awareness of the social order and rules by which culture evolves; fosters the understanding of African consciousness; facilitates a critical emancipatory approach to solve the problems of their lives; and produces the material and capacities for Africans to determine their own future(s). Such an educational system would result in the production of knowledge which is context relevant, effective and empowering [32].

Through Africanization, learners are encouraged and trained to challenge existing relations of power and domination and the curriculum is viewed as an instrument of empowerment [33] consciousness raising and the development of social awareness of prevalent influential relations that define the recipients of knowledge. ${ }^{34}$ All these become part of the mission of the curriculum and curriculum planning [35].It also involves teachers and policy makers who realize the importance of that which belongs to the continent and integrate it into the school and life of its pupils and students [36]. In terms of instructional materials Africanization of education requires that all the instructional resources are based on African structured or unstructured epistemology and indigenous knowledge systems to enhance transformation [37]. Such resources are fundamental in preparing a teacher who is determined to safeguard African values and tenets. The idea is that education will produce people who are not alienated from 
their communities and are sensitive to the challenges facing Africa [38]; a process of transformation as an 'Affirmative Action [39]

Mswazie and Muddyahoto have summarized the rationale for Africanization of education in three key areas. The first is the compelling curriculum seeing that -the cost of ignorance about each other has become far too great for Africa and the Diaspora to bear [40]. This knowledge gap in academia about African cultures' contribution to humankind is frightening and unjustified [41]. The second is the realization among scholars that Euro-centric models of development, namely liberal and Marxist blueprints have failed to emancipate Africa from its grinding poverty. This should lead to the quest for alternative strategies to African development [42]. The third most compelling reason for Africanization relates to neoliberalism and doctrine of globalization which again like colonialism is spreading models of relation that have their base in Western centres and privilege Western culture [43].

\section{Africanization of Education Project: An Appraisal of efforts}

Since 1957 when Ghana obtained independence, overt criticisms of colonial education and the need to Africanise have been heralded throughout the continent [44] [45]. In a UNESCO organized conference in Addis-Ababa in May 1961, the project was identified as a 'serious concern' for the development of education in Africa. African leaders understood that the growth of a wider consciousness and understanding of African cultural values, will only be effectively developed by an expansion in each nation of programmes of research on the traditions, the ways of thought and living particular to each country [46]. From this was to grow a larger conception and appreciation of African culture as a whole and of its contribution to the common cultural heritage of mankind [47]. The general appraisal hereunder reveals the road travelled so far. While doing that, we acknowledge the paucity of literature for which conclusions could be reached in some areas and countries.

As far as higher education is concerned, Africanization and other responsibilities attributed to this sector were discussed in workshops and seminars around Africa to help initiate these reforms. Beginning with the Tananarive conference (1963), on to Accra in 1973, discussions centred on how African higher education institutions could build African identities and sustain them within a competing world of cultures and most especially with the challenge of the colonial cultural backgrounds within which such institutions emerged[48]. Envisaged challenges notwithstanding, African states were unanimous in their efforts to work in 
coordination to overcome intellectual dependency, through the hastening of Africanization of staff and curriculum and the creation of new national institutions [49].

One of the early challenges that stood by the way of Africanization was the need to increase the proportion of local staff in education considering that most colonial institutions in Africa were manned by Euro-American personnel and research associates with the same mission of entrenching the colonial curriculum. Looking back by way of evaluation it is estimated that the proportion of African teaching staff has risen from 64 percent in 1978-79 to 84 percent in 198687 [50].This trend follows what Ramoupi and Ndille observed in the Africanization of university teaching staff in Africa which as of 2015 reached $100 \%$ in some countries except for South Africa where, the authors observed, policy in place has yet to privilege the rise of the African professoriate [51]. On a general note therefore, African countries have been given a positive score here.

Alongside the Africanization of academic staff was the question of the university curriculum where studies have taken particular interest in the Africanization of humanities such as history, linguistics, literature, religious studies and philosophy. These were seen as key disciplines in the achievement of the Africanization project. At this level, studies have pointed to curricula of some universities hardly undergoing any transformation; still dominated (as of 2018) by markedly European contents [52]. It has been argued that although some local history courses have been inserted in the curricula of some departments in the humanities, these courses do not significantly sway the curriculum to African-centeredness. Recently, a dean of a humanities faculty acknowledged that humanities have been seen in Africa as irrelevant for not being able to address the problems of their societies despite the fact that such problems have human origins; that the humanities faculties, instead of reacting extremely defensively, still need to provide a better account of themselves to the societies that house them [53].

The source of such criticisms come from the failure of the humanities to Africanize their curricula. Some studies have observed disappointingly how even some new generation universities in Africa, where a department of history offers twenty-four courses for the Bachelor's degree in History, only six focus on the country and African as a whole and how even recently designed $\mathrm{PhD}$ courses are over eighty percent Euro-American inclined. This is hardly the case in the North [54]. There is a perceived tint of interest in Africanization through the establishment of Centres for African Studies, as compromises for the weaknesses of university departments to Africanize their curricula. However, the justification for faulting 
universities in the Africanization project especially of the humanities is that the majority of undergraduate students pass through the departments for which the study of local contents is still highly compromised.

In a recent assessment, Cross and Ndofirepi (eds) confirm that universities in Africa are still semblances of western epistemologies propelling an encumbering and debilitating Eurocentric education, characterised by an attendant tenacity to exclude and marginalize an indigenous presence and 'ways of knowing [55]. Even where studies seem to look African, it is very much not African but rather a reflection of Europe in Africa [56].This is the source of the assertion by one head of department that 'in Africa, there is a widespread conception that historical studies is not a useful discipline, especially in preparing for a life after school in Africa [57].'

As far as the level of Africanization of the language of instruction is concerned, research has observed a disappointing move away from Mother Tongue Education in favour of colonial languages[58] despite the fact that research on language efficiency in educational achievement indicates that this trend is counter-productive[59]. This phenomenon has been described as 'baffling' for the africanization project [60] as it has been debated at length [61] that the use of colonial languages has never demonstrated a positive return on the investment in education [62].

Some researchers have noted with dismay, the proliferation of European cultural centres and clubs in urban areas and schools in Africa to the detriment of local languages [63] arguing strongly that this constitutes a linguistic insecurity as well as a downward trend in the Africanization of education project [64] for which not just government policy makers but also researchers, advisors and 'experts', must accept responsibility [65]. In a comparative perspective it has been observed that the Francophone and Lusophone countries of Africa are making very minimal efforts [66] than their Anglophone counterparts and this does not come as a surprise to history of colonial education experts [67]. For the particular case of South Africa, Ramoupi's [68] policy review of language in education in the past 20 years of liberation has a similar conclusion that school instruction is gradually being narrowed down to English and Afrikaans despite the inclusion of African languages among the official languages with equal standing [69]. In terms of language of instruction therefore, the africanization project is still to take root. 
A particular area which would have served as a point of consolation in the Africanization of education is in the school curriculum where transformations are said to have occurred in some areas. However, as studies have demonstrated, the bulk of social studies subjects in primary and secondary schools are still weighed down by contents about Europe, America and Asia, which is hardly the case in such countries [70]. In Zimbabwe for instance, Tapfumaneyi's 2013 survey of the situation has concluded that the various curricula in the country 'are too dependent on Western knowledge systems well after the colonising authority relinquished power to the black political elite [71]. A look at the Zimbabwe national Report to UNESCO supports Tapfumaneyi's conclusions. In a forty-one page policy document Africanization is not mentioned [72].

Studies conducted in Nigeria reveal the de-emphasis on Africanization in the National Policy of Education (NPE). What emerged in the 1969 document (with recent revisions) that marked the end of 135 years of a Eurocentric curriculum was a disappointment to the Africanization project. Oluniyi and Olajumuke have revealed that the extent to which the curriculum was Africanised could only be seen in its positive pronouncement on the use of local languages as medium of instruction which like the British era, limited it to the first three years of primary schools [73]. This, in the majority, is not being practiced, especially with the development of urban private primary schools whose extent of westernization is the basis of attraction of students. Like in Zimbabwe, social studies was programmed, but it was more directed to ethics and national unity for which Ibukun and Aboluwadi have agreed, had nothing to do with Africanization. Rather, as they suggested, a well-planned African and national history curriculum would have fulfilled such a project [74].

A comprehensive analysis of educational reforms in Botswana, Kenya and Tanzania which was to serve as a lesson for Namibia by Albertus Kuzeeko Kangueehi has brought out some insights of the Africanization projects in these countries. In Botswana, Africanization of education took the form of what was locally known as Education for Kagisano which simplistically, is concerned with Africanization thought [75].This was characterised by a rejection for colonial day practices in education; the setting up of national university of Botswana and Swaziland; improvement and localization of school activities through the indigenization of contents and educational management. The author concludes that 'attempts at Africanization seemed to have achieved a great deal in Botswana under the Kagisano ideology except for the medium of instruction which is still characterised by instruction in English but regretted that this 
perspective is gradually being reduced to entrepreneurship, science and technology which point to neo-liberal tendencies [76].

Similar to Botswana was the education for self-reliance (ESR) in Tanzania initiated in 1967. ESR was inspired by the need to develop curriculum and school systems to meet the needs of the majority of Tanzanians who were living in rural areas. But it was criticised for preparing students for a permanent rural life, and for being associated with the socialist transformation of society which Nyerere's Ujaama African socialism hoped to bring. A remarkable plus of the system however is that the study of local history and culture was emphasized and Swahili became a media of education alongside English. There was also the establishment of the Wabena project in 1982 which set up what became known as 'country folk schools' in 168 villages as centres of research and community transformation [77]. Management was also community based and laws, customs and standards of operation were indigenous [78]. These notwithstanding, self-reliance did not succeed because efforts were linked to the political economic system of socialism and most of the projects collapsed [79].

In Kenya efforts at africanization were fixed in the country's four year development plans initiated by Jomo Kenyatta in 1963 with Harambee a slogan meaning lets pull together becoming a national education ideology. It was characterised by the removal of western and Christian hold on the educational system and the focus of curriculum to render students economically useful within their own environment [80]. This did not however lead to curriculum transformation as the teaching of history and literature remained predominantly European despite the introduction of a few local texts [81].While the primary school curriculum saw seen some degree of Africanization, the Kenyan secondary school curriculum is still being criticised for neglect of African history and literature and for its Euro-centric bias [82]. The curriculum remains, in the words of Ngugi wa Thiongo, 'a form of cultural genocide' that perpetuates intellectual dependency on the West [83].

In Cameroon, authorities adopted ruralisation as one of the four key tenets of educational philosophy of the 1961 federal government but this programme was not different from Nyerere's Education for Self Reliance and its implementation did not pass the experimental phase of the 1970s [84]. Its curriculum prepared by the Institute of Rurally Applied Pedagogy known by its French acronym IPAR, was never tested and its teacher training programme brought massive confusion within the teaching corps [85]. Its attempt to unsuccessfully 
duplicate the Adaptation philosophy of the 1920s has been termed 'replacing six with half a dozen [86].

An attempt to examine the situation in some French West African countries reveals even more disappointing results. Monica Naida and Eliot Chilton have undertaken studies of the present state of the Africanization project there [87]. Naida reveals the French West African elites continuous privileging of the French language and curriculum structure [88]. Chilton on his part takes a more focused study of Senegal, whose first leader with his philosophy of negritude was viewed by many as a strong defender of the Africanization project. He argued that since the days of Senghor, education policy had identified three focal points which to Senghor were derived from the three heritages of the country; traditional African heritage, Islamic heritage and French colonial heritage [89].

Such a policy didn't favour africanization as Senghor didn't push for radical reforms to completely overhaul the colonial system while allowing the triple heritage to work for a more culturally balanced future for Senegal. The result is that the image of "that which is French is best' continues to pervade the contemporary Senegalese society and the entire French African countries like ivory coast, Benin, Togo, Gabon etc [90]. Chilton argues that, the triple heritage policy allows for selectivity in reconstructing a historical discourse for the country that privileges the French [91]. He paints a picture from a discussion he had with one resource person; a university drop-out-yet for the same reasons;

...he can speak French so well because his teacher told him that he must think in French; that you cannot think in Wolof and translate to French. I ask why they keep the French system. He says, they speak French in the offices, they speak it everywhere. He lists the subjects and stops at history. He says, with some frustration that they only learn the history of France, of the United States, the cold war and Russia, the First war, the second. He says, some people know the story of others in these places better than they know the story of themselves and their country [92].

Chilton has argued that education impacts identity in French Africa. That's why this is allowed to continue. If someone has studied in French (as in the days of assimilation) you can feel it. If someone has studied in Arabic, you can also feel it. If someone has not studied then he must have studied Wolof. You can still feel it. What you study changes who you are and presumably you are best of the three if you study French [93]. This can tell the extent to which French leaders are interested to Africanize their educational systems. 
A key function of the Africanization project is the Africanization of the teaching programmes of teacher training colleges in the same way as these are expected to be implemented in the school systems or initiate bottom top proposals for reform. Unfortunately too in this domain, findings have revealed 'the inadequacy of the existing teacher training programs [94].' Guro has assessed that current and dominant teacher-training programs were developed before most African countries got their political independence and cases of revision have not initiated significant curriculum reforms to reflect an African knowledge base [95]. In this regard Guro concludes that, in most parts of Africa student-teachers are being prepared as hitherto to teach contents and in languages that are unfamiliar to children [96].

Conclusions from the brief surveys of the extent of implementation of Africanization in some parts of the continent point to a similar conclusion by Woolman that 'reform of inherited educational systems that largely functioned to maintain the colonial order of dependency and elitism which was the general cry in Africa at independence has not been undertaken and that the colonial order is still very much in place in most parts of the continent [97]. Although there may be few exceptions to the rule, the empirical sources reflect the position of a very limited success of the Africanization of education reform especially in curriculum contents and language of education. This position is reflected in Edward shizha's study of the entire SubSaharan Africa. He concludes that

Most countries in this category have been politically independent since the late 1950s but they have not done much to free their school curricular from remnants of colonial education.' The current postcolonial African school curriculum ignores the voices, indigenous knowledges (IKs) and cultures of African indigenous populations. Students, in Africa, experience barriers in learning because of the dissonance between the school curriculum and their cultural experiences. What the schools teach, and how teachers disseminate and transmit knowledge does not reflect the cultural symbolic conventions (collaborative and participatory learning) and representations (knowledge constructs, symbols and cultural beliefs) of the students' cultural experiences [98].

\section{Challenges to the Africanization Project}

The section above has demonstrated that while states have made nice pronouncements regarding the relevance of Africanization, there is little to justify their faith in the project considering that there is very little proof on the ground as sustained implementation plans and actions followed by monitoring and evaluation. What then constitutes the impediments of the 
project? An understanding of these challenges may be significant in refocusing efforts towards a rational implementation of the project.

One of the major challenges to Africanization has been the question of multiculturalism. It is being argued that Africanization has been wrongfully pitted against the process of multiculturalism [99]. It is argued that an Africanized curriculum 'replicates the same colonial form of eradication in which the non-western collective memories that certain students brought to the classroom were declared [100] as non-knowledge. A curriculum that is fit for the contemporary multicultural societies which most people live in today is one that opens the space for 'diverse ontological narratives' rather than one that insists on 'erasure or a Euroethnic mono-discourse [101].'

Closely linked to the multicultural discourse is the compounding situation of globalization. Advocates of globalization have argued that, there is need for 'a fitting of the various African societies into globalization which may require the internationalization of education rather than Africanization $\left[{ }^{102}\right]$ as globalization entails the transforming not only of the external factors but also the internal principles and priorities of nations. This school holds that globalization is important and that the more a country chooses to Africanise the less it can internationalise, and vice versa [103].

This argument has however not been digested by all. There is a school of thought which maintains that in order to be participants in internationalisation, African countries rather need to create their own identities through Africanization programmes. They argue that 'if you do not know who you are, you wouldn't have much to offer your international counterpart [104].' It is only when 'one has a deep understanding of his/her experiences that one is able to conquer knowledge and concepts that are not part of that experience [105].' According Letseka rather than view Africanization as attempts to delink from metropolitan control it should be viewed as a contribution of non-western systems of thought to theories and ideas. These discourses are informed by local historical experiences and cultural practices in the same way as Western discourses [106].

Some scholars rather argue that globalization is one of the greatest stumbling blocks for the Africanization project as it is said to have corrupted African culture by promoting the epistemological and ontological realities of the most powerful in the world and therefore catalysed the colonisation of African ways of knowing even more [107].They hold that globalization is hegemonic and has generated discursive scientific practices and interpretive 
frames that make it difficult to think outside of those frames. It calls for a restructuring of education closely related to the dynamics of global capitalism which is detrimental to Africanization because it actively represses anything that is articulated, thought and envisioned from outside of its own framework [108].

Globalization is also said to have masqueraded today as the 'global knowledge economy' with a hegemonic centre (Europe and North America) [109]. As it continues to incorporate modern African institutions and their staff and students with a definitely western oriented geography of production and circulation, the Africanization project and scholarship is marginalized. This marginalization is part of a deliberate division of labour rooted in imperialism and colonialism in which scholars of Africa abandon producing knowledge for the African knowledge base and rather become 'native informants' or 'hunter-gatherers of raw data for the North that is turned into theories in the Global North for African consumption [110]. In such circumstances africanization would hardly survive.

Apart from external forces, scholars have also identified that a huge impediment to Africanization remains the Africans themselves. This includes the academics produced by westernised universities. This is what some scholars have termed 'our mentalities and consciousness' being the centrality of the problem [ $\left.{ }^{111}\right]$.' It is argued that the African intellectual suffers from the alienation that was imposed on Africans by a particular form of education they received and which continues to actively promote coloniality long after the end of direct colonialism. This state of being makes the African intellectual to aspire to make the institutions they create in Africa local branches or affiliates of dominant European academic models. It is therefore not a surprise that even the newly established institutions have become close replicas of their Eurocentric host universities. Because they have not moved away from that mentality of aping and replicating western hegemonic epistemologies on all fronts Africanization of education has been jeopardized for the production of what Claude Ake described as 'knowledges of disequilibrium'[112].

Another challenge to the Africanization project is the western dominance of the dissemination of knowledge and information in Africa seen in the over-reliance on Western textbooks [113]. According to UNESCO, The source of inspiration of teachers, curricula and textbooks is Western. Teachers are mostly Western educated, curricula are drawn from Western models and most textbooks are authored and published in the West and North America [114]. Studies conducted in Nigeria by Mukasa and Becker underline the same dependency syndrome. Their studies reveal that out of a survey of 20 randomly selected papers read at a communications 
conference in Nigeria recently, $87 \%$ of citations were from Western sources, suggesting that there is a heavy dependence on Western thought patterns in Nigerian education [115]. An extensive survey on the teaching of journalism and media studies in Africa by Mano in 2009 [116], also revealed that there is an over-dependency on syllabuses conceived in the West; that most students and staff are still trained abroad; and that major books and theories used in African institutions were mainly written by Westerners for Western students.

Apart from the above, there are some who have argued against the very conception of the Africanization project. Long argues that Africanization has become a kind of ' call to difference'[117] while Gareth has termed it 'polemical position taking'[118]. Gareth intimates that there is 'an upheld obsession of what it means to be African' which has substantially kept other cultural representations in Africa out of the picture such as the European settlers. Africanization therefore articulates an essentialist politics of ethnic assertion, cultural chauvinism, pan African Black Nationalism [119]. In this context, the project is bound to be opposed by those it tends to challenge.

Still within this context, there is the argument that African leaders are not consistent with the Africanization ideology. It is held that while some have argued for 'the pursuit of knowledge and truth with a purpose and social responsibility as what an African educational intuition should focus on [120] they have not been consistent in this mission. In many countries, where policies of africanization were laid out, they were soon abandoned instead of being improved upon. Leaders chose at the same time to follow the worldwide trends of replacing the pursuit of truth with western corporate friendly notions of education typical of globalization [121].

Finally, there is the challenge of the languages of instruction. It is argued that colonialism left a legacy of alien, European official languages in all countries. Each country has numerous African languages, and many indigenous speakers are multi-lingual. Nevertheless, literacy and proficiency in the alien official languages is one criterion for indigenous elite class formation that reproduces the caste system created by colonialism [122]. Woolman argues that it is difficult to indigenize the language of instruction policy because, in most of the multi-lingual African countries, language policy reflects the need to preserve national unity by not granting official preference to any one African language. In addition to offering a culturally-neutral means of communication, the alien European languages provide continuity with colonial political foundations and a basis for essential contact with the outside world. Because of this, language of instruction policy after independence has been marked by very limited Africanization [123]. 


\section{Prospects of Africanization}

There is a significant justification for the Africanization project and a seemingly common consensus regarding the necessity of its implementation in Africa as calls have indicated. While there are indications that some countries actually took up the implementation of the project albeit failures/weaknesses, there are however others who have not demonstrated any change of mind-set from the colonial period. The challenges have thus been viewed as being external as well as internal. What then can be the best way out for the revival and sustenance of the project in African countries? While recognizing the pressure of the external factors, a significant voice has pointed to the African leaders inability or unwillingness to come to terms with what is required to Africanize; a bold and determined African leadership [124] that exhibits elaborate attributes of being different from the ones Fanon termed the national middleclass whom he described as lazy, unscrupulous and parasitic and lacking spiritual depth because they had completely assimilated colonialist thought in its most corrupt form [125]. Evidently, Africanization could not have succeeded (or cannot succeed) with such people at the helm of affairs.

This is the position of Decolonial theorists who have suggested Delinking as route in the attainment of Africanization. Delinking is a careful strategy that takes the form of a transition during which underdeveloped countries would adopt new strategies and values that are different from those of the developed nations. It also means a consistent refusal to bow to the dominant logic of the world capitalist system. It is the pursuit of a system of rational criteria for indigenous socio-cultural, political and economic options. Such options are founded on a law of value on a local/national basis with popular relevance, independent of such criteria of socio-economic rationality as flows from the dominant capitalist law of value on a world scale [126].

Walter Mignolo has since elaborated on the delinking thesis insisting however that Delinking must be a break and not a transition. According to Mignolo, 'capitalism or socialism, as they are currently constituted, are not the answers to Global south problems. He writes;

One way to delink is precisely through dewesternization. Dewesternization is not a geographic but a political concept and refers to all States (corporate states) which are consolidating their economies and societies without following the dictates of the US, the EU, the IMF or the World Bank. Delinking here does not 
mean delinking from "a type of economy" but from the ideas, suggestions or instructions of Western countries, [as well as] the World Bank, the IMF and related institutions. The delinking is contained in the sphere of authority in ending international dependency on the legacies of the West and its Bretton Woods as well as ending the reign of the dollar. De-westernization is, at a basic level, a political delinking from economic decisions... the idea of delinking has to do with who is making the decisions regarding the politics of development, and this should include decisions about the curriculum [127].

When African leaders delink, they would be able to act on their own. When they delink, they would see African values as parity with European values. When they delink, they would be able to initiate curriculum contents and implementation strategies that do not emanate or resemble nor replicate that of the West. Teacher training institutions and universities will be more society and local problem-solving centres. Within a long run, African knowledge bases would be significantly relevant in solving world problems and recognized as African, rather than the present situation where such knowledge basis are bought over, transformed and resold to the content as European products. With Africanized indigenous educational systems, Africa will take her place on the world stage.

\section{Conclusion}

We have examined what we mean by africanization and its relevance. We have also discussed efforts around the continent with the observation that efforts so far in the implementation have not been commensurate to the calls of the 1960s which made the project seem imperative. We identified some areas where efforts actually took off but were soon overtaken by other economic and political exigencies which we identified as both internal and external. We also identified areas where the project doesn't seem to have interested the leaders at all. Challenges have included the present scourge of globalization which, as it has been argued propagates the same characteristics which inspired colonialism as well as the African intellectuals and political leaders themselves. We have concluded therefore that Africanization may have been easy to proclaim but implementation goes beyond the proclamations which filled public spaces in the 1960s. African leaders must delink with the colonial past and then initiate a new discussion regarding what they mean by Africanization, draw up implementation strategies, time plans as well and monitoring and evaluation strategies for the project to be effective. 
Author Contributions: The Article was conceptualized, Researched and developed by the lone Author

Funding: The paper received no funding but was prepared as part of the author's PDRF research responsibilities under the supervision of Prof. Linda Chisholm

Acknowledgments: The author thanks the editor and the reviewers for their thoughtful comments and suggestions on this paper.

Conflicts of Interest: The author declares no conflict of interest.

\section{References}

[1] Ndille, R. Britain and Education in the Development of Southern Cameroons: A critical Decolonial Historiographical Analysis. D.Litt. et Phil Thesis, University of South Africa. 2014

[2] Aissat, D.; Djafri, Y. 'The Role of Education in Retrospect: The Gold Coast in the Era of Imperialism', University of Andelhamid, Ibn Badis, Algeria, 2011;

[3] Ndlovu-Gatsheni, S.J. The entrapment of Africa within the Global Colonial Matrices of Power: Eurocentrism, Coloniality, and the Deimperialization in the Twenty-first Century. Journal of Developing Societies. 2013, 29:4, pp.334 349.

[4] Awasum, S.S. The Challenging Beginnings of a Great Educational Project. in Sasse Chronicles 1939-2014: A Special Diamond Anniversary Publication of St Joseph's College Sasse and Sasse Old Boys Association, 2014, pp.17-19.

[5] Tamanji, A.C. Three Instances of Western Colonial Governments and Christian Missions in Cameroon Education: 1884-1961. PhD Thesis, Loyola University, Chicago, 2011 
[6] Read, M. Africans and their Schools. British Commonwealth Affairs London: Longmans Green and Co, 1953, 8. p.13.

[7] Rodney, Walter. How Europe Underdeveloped Africa. Washington: Howard University Press, 1982, p.377.

[8] Said, E. Orientalism. New York: Random House, 1978, p.9

[9] Elume R. How Sasse Transformed Three Generations of Successful Men. in Sasse Chronicles 1939-2014: A Special Diamond Anniversary Publication of St Joseph's College Sasse and Sasse Old Boys Association. 2014, pp.32-33.

[10] Grosfoguel, R., Decolonizing Post-Colonial Studies an Paradigms of Political-Economy: Transmodernity, Decolonial Thinking, and Global Coloniality. Transmodernity: Journal of Peripheral Cultural Production of the Luso-Hispanic World. 2011,1:1, pp.119

[11] Whitehead, C. The Historiography of British Imperial Education Policy, Part II: Africa and the Colonial Empire. History of Education: Journal of the History of Education Society, 2005, 34:4, pp. 448.

[12] Ndille, R. Britain and Education in the Development of Southern Cameroons: A critical Decolonial Historiographical Analysis. D.Litt. et Phil Thesis, University of South Africa. 2014

[13] Whitehead, C. The Historiography of British Imperial Education Policy, Part II: Africa and the Colonial Empire. History of Education: Journal of the History of Education Society, 2005, 34:4, pp. 448.

[14] Singh, Abhaey, The greatest cover-up in history: How imperial racist India, Africa and China Narrative still persists. in The Huffingtonpost of 7 April 2011 available at www.huffingtonpost.co.uk/abhaey-singh. Accessed 02/09/2013, 2:30 pm

[15] The Times, April 13, 2018 available at www.thetimes.co.uk/article/primeminister. accessed 27 July 2018.

[16] Ilaigwu, J.I. and Mazrui, A.A. Nation Building and Challenging political structures, in Mazrui, A and Wondji, C. UNESCO General History of Africa, Volume 8. Paris: UNESCO, 1999, pp.435-467.

[17] W.D., Mignolo, 'Epistemic Disobedience, Independent Thought and Decolonial Freedom', Theory, Culture \& Society 2009, 26:7, p.159.

[18] Schofield, H., The philosophy of education: an introduction. London: George Allen and Unwin. 1978.

[19] Wane, N.N. Mapping the field of Indigenous knowledge in Anti-colonial Discourse: A Transformative Journey in education. Race, Ethnicity and education, 2008, 2:2, pp.183197.

[20] Velasquez, M. Philosophy; a text with readings. Belmont, CA: Wadsworth Publishing Company. 1997.

[21] Rodney, W. How Europe Underdeveloped Africa. Washington: Howard University Press. 1981.

[22] Mwinzi, J. M. Towards the Africanization of Teacher Education: A Critical Reflection. International Journal of Education and Research. 2016, 4:9, pp. 377-387.

[23] MacOjong, T.T., Philosophical and historical foundations of education in Cameroon 1884-1960, Limbe: Design House. 2008.

[24] Ndille, R.N. Education for Development: British Impact on Southern Cameroons. MA Thesis at the Centre for African Studies, Dalarna University, Falun, Sweden. 2007.

[25] MacOjong, T.T. Philosophical and historical foundations of education in Cameroon 1884-1960, Limbe: Design House. 2008.

[26] Smith, L.T. Decolonizing Methodologies: Research and Indigenous peoples, London: Zed Books LTD, 1999 
[27] Ndille, R.N., Indigenization and/or Globalization: Is African historiography caught between the hammer and the hard place? In Odukoya, A.O., Alternative Development Strategies for Africa: Lagos: Centre for African Arts and Civilization (CBAAC), 2013, pp.27-46.

[28] Louw, W. Africanisation: The Delima to Africanize or to Globalize a Curriculum. Conference of the Interntional Journal of Arts and Science, 2009, 1:6, pp.62-70.

[29] Ramoupi, N., and Ndille, R. Africanization of Knowledge in the Universities in Africa: A Critique of the Cameroon and the South African experiences.' In Cross, M., and Ndofirepi, A., (eds) Knowledge Change in African Universities, Rotterdam: Sense Publishers, 2016, 1, pp.195-215

[30] Msila, V., Fostering Africanization: A Lesson of Identity Formation among Youth. Mediterranean Journal of Social Sciences, 2014, 5:8, pp.431-441

[31] Louw, W., Africanization: The Dilemma to Africanize or to Globalize a Curriculum, 2009, p.65

[32] Nkoane, M.M. Constructing Knowledge through Learner-centred Approach Unpublished paper. Presented at the University of Witwatersrand, Johannesburg. 2002

[33] Msila, V. Fostering Africanization: A Lesson of Identity Formation among Youth. Mediterranean Journal of Social Sciences, 2014, 5:8, pp.431-441.

[34] Mwinzi, J. M. Towards the Africanization of Teacher Education: A Critical Reflection. Journal of Education and Research. 2016, 4:9, p.382

[35] Emeagwali, G. African Indigenous Knowledge Systems (AIK): Implications for the curriculum. 2005.

[36] Mwinzi, J. M. 'Towards the Africanization of Teacher Education: A Critical Reflection. International Journal of Education and Research. 2016, 4:9, pp. 377-387

[37] Ibid, p.383

[38] Naidoo, M. Overcoming Alienation in Africanizing Theological Education. Theological Studies 2016, 72:1, p.1

[39] Ndlovu-Gatsheni, S.J. Decolonizing the University and the Problematic Grammars of Change in South Africa: Keynote Address Delivered at the 5th Annual Students Conference on Decolonizing the Humanities and Social Sciences in South Africa/Africa, University of KwaZulu-Natal, 6-7 October 2016. P.18.

[40] Mswazie, J,; Muddyahoto, T. Africanizing the Curriculum: An Adaptive framework for Reforming African Education Systems. Journal of emerging trends in Educational Research and Policy Studies. 2013, 4:1, pp.170-177.

[41] Ibid, 2013, p.173.

[42] Ibid, 2013, p.173.

[43] Diang. M.C. Colonialism, Neoliberalism, education and culture in Cameroon, DePaul University College of Education Paper 52, 2013.

[44] Ndille, R.N., Towards the Indigenization of the History Curriculum in Cameroon 18842001: Implications for the shift in paradigm to African historiography 1884-2001. Peace and Security for African Development. Pretoria: Africa Institute of South Africa (AISA), 2012, pp.132-159.

[45]Bangura, A.K., Ubuntugogy: An African Educational Paradigm that Transcends Pedagogy, Andragogy, Ergonagy and Heutagogy. Journal of Third world studies, 2005, 22:2, pp.1-33

[46] UNESCO, Conference of African States on the Development of Education in Africa: Final Report. Paris: UNESCO. 1961, p.3.

[47] Ibid. 1961, p.3.

[48] Woldegiorgis, E. T. and Doevenspeck, M. Changing Role of Higher Education in Africa: A Historical Reflection. Higher Education Studies. 2013, 3:6, pp.35-46.

[49] Ibid, 2013, p.36. 
[50] Ibid, 2013, p.36.

[51] Ramoupi, N.; Ndille, R.N. A Critique of the Discourse on the Africanization of Knowledge in the African University. in Cross, M. and Ndofirepi, A. (eds.) Knowledge Change in African Universities Vol. 1: Current Debates. Rotterdam: Sense Publishers, 2017, pp.193-205.

[52] Ibid, 2017, p.193

[53] University of Johannesburg, Faculty of Humanities Strategic Plan 2020. Johannesburg, University of Johannesburg. 2017, p.1.

[54] Ndille, R.N., Towards the Indigenization of the History Curriculum in Cameroon 18842001: Implications for the shift in paradigm to African historiography 1884-2001. Peace and Security for African Development. Pretoria: Africa Institute of South Africa (AISA), 2012, pp.132-159.

[55] Cross, Michael and Ndofirepi, Amasa (eds), Knowledge and Change in the African Universities. Rotterdam: Sense Publishers, 2016, p.1

[56] Ngugi, W.T., Decolonizing the Mind. Portsmouth: Heinemann Educational Books. 1986.

[57] University of Johannesburg, Faculty of Humanities Strategic Plan 2020. Johannesburg, University of Johannesburg. 2017, p.26

[58] Plonski, P.; Asratie, T.; Bradi, R. Why are More African Countries Adopting English a Official Language? Conference Paper presented during the African Studies Association Annual Conference, November 23, 2013

[59] Wolff, H. E. Background and History: Language Politics and Planning in Africa. In Alidou, Hassan, Aliou Boly, Brigit Brock-Utne, Yaya S. Diallo, Kathleen Heugh and Wolf. H. Ekkehard. Optimising Learning and Education in Africa-Language Factor: A stock Taking Research on Mother Tongue and Bilingual Education in Sub-Saharan Africa. Paris: ADEA, 2006

[60] Heugh, K. Theory and Practice: Language Education Models in Africa: Research Design, Decision-Making and Outcomes. In Alidou, Hassan, Aliou Boly, Brigit Brock-Utne, Yaya S. Diallo, Kathleen Heugh and Wolf. H. Ekkehard. Optimising Learning and Education in Africa-Language Factor: A stock Taking Research on Mother Tongue and Bilingual Education in Sub-Saharan Africa. Paris: ADEA, 2006, p56.

[61] Wolff, H. E. Background and History: Language Politics and Planning in Africa. In Alidou, Hassan, Aliou Boly, Brigit Brock-Utne, Yaya S. Diallo, Kathleen Heugh and Wolf. H. Ekkehard. Optimising Learning and Education in Africa-Language Factor: A stock Taking Research on Mother Tongue and Bilingual Education in Sub-Saharan Africa. Paris: ADEA, 2006, p.25

[62] Ibid, 2006, p.56

[63] Ndille, R.N. 'English and French as official languages in Cameroon: The Intentionality of Colonial Representations and the Failure of a Cameroon-centric Identity; 1884 and after.' European Journal of Language Studies, 2016, 3:2,pp. 17-34.

[64] Ibid, 2016, pp.20.

[65] Wolff, H. Background and History: Language Politics, 2006, p.25.

[66] Ibid 2006, p.25.

[67] Ibid, 2006, p.25

[68] Ramoupi, N.L. The Imperative of African African-centred Curriculum in South Africa, Pretoria: Africa Institute of South Africa Publisher, 2012

[69] Ramoupi, N.L, African Research and Scholarship: 20 Years of Lost Opportunities to Transform Higher Education. Ufahamu: A Journal of African Studies, 2014, 38:1, pp.269-287.

[70] Ndille, R., 'Towards the Indigenization of the History Curriculum in Cameroon 18842001: Implications for the shift in paradigm to African historiography 1884-2001in 
Peace and Security for African Development. Pretoria: Africa Institute of South Africa (AISA), 2012, pp.132-159.

[71] Tapfumaneyi, K.D., Reordering Education. Potential Benefits and Challenges: Africanizing the Education Curriculum. International Journal of Advanced Research, 2013, 4, pp.536-542.

[72] Zimbabwe, The Development of Education: The Education System at the End of the $20^{\text {th }}$ Century 1990-2000. National Report presented to UNESCO. February 2001, p.12

[73] Oluniyi, O.; Olajunmuke A.C. Curriculum Development in Nigeria: Historical Perspectives. Journal of education and social Research, 2013, 3:1, pp.73-81.

[74] Ibukun, W.O.; Boluwudi, A. Nigeria's National Policy on Education and University Curriculum in History: Implications for nation Building. Journal of Education and Practice. 2010, 1:2, pp.9-18.

[75] Kangueehi, A. The Possibility of Africanizing the Curriculum of Namibia in the Light of the African Experience. M.Ed Thesis, UNISA, 1995, p.146.

[76] Ibid, 1995, p.147.

[77] Ibid, 1995, p.155.

[78] Ibid. 1996, p.167.

[79] Ibid. 1995, p.168.

[80] Ibid, 1995, p.174

[81] Ibid, 1995, p.192.

[82] Woolman, D.C., Educational Reconstruction and Postcolonial Curriculum Development: a comperative study of four African Countries, international Education Journal 2001, 2:5, pp.27-57.

[83] Ngugi, W.T. Decolonizing the Mind, The Politics of Language in African Literature. London: James Currey, 1986

[84] Ndille, R.N., 'From Adaptation to Ruralization of Education in Cameroon: Replacing Six with Half a Dozen' African Educational Research Journal, 2015, 3:3, pp.153-160

[85] Tosam, J.F. Implementing Educational Change in Cameroon: Two Case Studies in Primary Education. PhD Thesis, University of London. 1988.

[86] Ndille, R.N., 'From Adaptation to Ruralization of Education in Cameroon: Replacing Six with Half a Dozen’ African Educational Research Journal, 2015, 3,3, pp.153-160.

[87] Naida, Monica, 'Senegal's Language Problem: A Discourse of Disparity. Honours Thesis, West Michigan University, 2016.

[88] Ibid, 2016, p.7.

[89] Chilton, India Eliot. Meaningful Learning in the Senegalese Educational System: Problems of Language, culture and Colonization. BA Thesis, Robert D. Clark Honours College. 2016, p.7

[90] Ibid, 2016, p.7

[91] Ibid. 2016, p.8

[92] Ibid, 2016.p.17

[93] Ibid. 2016.p.17

[94] Guro, M.Z. Basic Reform in Mozambique: The Policy of Curriculum Change and the practices at Marrere Teachers' College. PhD Thesis, University of Pretoria, 2009, p.122

[95] Ibid, 2009, p.122

[96] Ibid, 2009, p.122

[97] Woolman, Education reconstruction, 2001

[98] Shizha, E., Rethinking Contemporary African School Knowledge: Restoring the Indegenous African cultures: International Journal for Cross-discipline Subjects in Education. 2014, 4,1, pp.1870-1880 
[99] Letsekha, T. Revisiting the Debate on the Africanization of Higher Education: An Appeal for a Conceptual Shift. The Independent Journal of Teaching and Learning. 2013, 8, p.13

[100] Ibid, p.13

[101] Ibid, p.13

[102] Crossman, P. "Perceptions of "Africanization" or "Endogenisation" at African Universities: Issues and Recommendations' In P.T. Zeleza \& A. Olukoshi (Eds.) African Universities in the Twenty-First Century Vol.2 Dakar: CODESRIA, 2004, pp.319-340.

[103] Botha, M.M. Compatibility between internationalizing and Africanizing higher education in South Africa' Journal of Studies. International Education 2010, 14:2, pp.200-213.

[104] Neale-Shutte, M. \& Fourie, J. Challenges to internationalisation in African higher education' South African Journal of Higher Education 2006, 20:1, pp.118-142.

[105] Dowling, D. \& Seepe, S. Towards a responsive curriculum' In S. Seepe (Ed.) Towards an African identity of higher education. Pretoria: Vista University 2004, pp.185-189.

[106] Letsekhe, T. 'Revisiting the Debate on Africanization, 2013, p.8

[107] Ibid, 2013, p.8

[108] Mbembe, A. Decolonizing Knowledge and the Question of the Archive, Workshop Paper at the Wits Institute for Social and Economic Research (WISER) Wednesday, April 22, 2015. Pp.33, 37.

[109] Ndlovu-Gatsheni, S.J. Decolonizing the University and the Problematic Grammars of Change in South Africa: Keynote Address Delivered at the 5th Annual Students Conference on Decolonizing the Humanities and Social Sciences in South Africa/Africa, University of KwaZulu-Natal, 6-7 October 2016. P.18.

[110] Ibid, 2016, p.18

[111] Ibid, 2016, p.18

[112] Ibid, 2016, p19

[113] UNESCO, Educational reforms and innovations in Africa: Studies prepared for the conference of ministers of education of African Member states of UNESCO. Paris: UNESCO. 1978

[114] Ibid

[115] Woolman, D.C., Educational Reconstruction and Postcolonial Curriculum Development: a comperative study of four African Countries, international Education Journal 2015, 2:5.

[116] Ibid, 2001

[117] Long, W. The Africanization of Psychology. South African Journal of Psychology, 2016

[118] Gareth, C. On the Africanization of English Studies in South Africa. Arts and Humanities in Higher Education. 2006, 5:2, pp.117-126.

[119] Ibid, p.118

[120] Makgoba, M. M. The Makgoba Affair - A Reflection on Transformation. Vivlia: Florida. 1997, p. 180

[121] Ibid, 1997, p.179.

[122] Woolman, D.C., Educational Reconstruction and Postcolonial Curriculum Development: a comperative study of four African Countries, international Education Journal, 2001, $2: 5,2001$.

[123] Ibid

[124] Wessels, N. Decolonization of education in South Africa: A Basic Education Problem, in Diggit Magazine 31 July 2017. Available online at 
https://www.diggitmagazine.com/papers/decolonization-education-south-africa accessed on 25/07/2018 at 2:23pm

[125] Fanon, F. The Wretched of the Earth, Middlesex, Penguin Books, 1967, p.119

[126] Ndlovu-Gatsheni, The Entrapment of Africa, 2013.

[127] Mignolo W., Escobar A., (eds) Globalization and the Decolonial Option. London: Routledge, 2011. 